\title{
A framework for prioritising practices to overcome cost-related problems in reverse logistics
}

\author{
Authors: \\ Amanda Badenhorst ${ }^{1}$ \\ Affiliations: \\ ${ }^{1}$ Department of Transport \\ Economics, Logistics and \\ Tourism, University of South \\ Africa, South Africa \\ Correspondence to: \\ Amanda Badenhorst \\ Email: \\ badena@unisa.ac.za \\ Postal address: \\ 5 Hannington Place, \\ Blenheim Road, Lynnwood \\ Glen, Pretoria 0081, \\ South Africa \\ Dates: \\ Received: 31 July 2013 \\ Accepted: 09 Oct. 2013 \\ Published: 22 Nov. 2013 \\ How to cite this article: \\ Badenhorst, A., 2013, 'A \\ framework for prioritising \\ practices to overcome \\ cost-related problems in \\ reverse logistics', Journal of \\ Transport and Supply Chain \\ Management 7(1), Art. \#113, \\ 10 pages. http://dx.doi. \\ org/10.4102/jtscm.v7i1.113

\section{Copyright:} \\ (C) 2013. The Authors. \\ Licensee: AOSIS \\ OpenJournals. This work \\ is licensed under the \\ Creative Commons \\ Attribution License.
}

Read online:

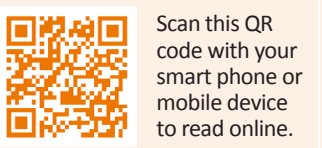

Reverse logistics has gained increasing attention in recent years. One of the biggest problems for organisations and supply chains is reducing cost in reverse logistics. This study attempted to gain a better understanding of reverse logistics and the costs associated with it. A literature study was conducted to identify the cost problems in reverse logistics and possible practices to overcome them. Following that, a survey was conducted to determine whether the practices identified in literature are perceived to be important in South Africa and if they are viable to implement. This was done by means of a gap and opportunity analysis. Results indicated that most practices are important, but some may be difficult to implement. The framework developed in this study provides a guideline for organisations to consider, adapt and adopt the most important implementable practices to overcome cost problems in reverse logistics. The limitation of this study is that only ten respondents participated in the survey. The approach followed in this study can be used as a foundation for future studies in reverse logistics.

\section{Introduction}

Reverse logistics has become a popular research topic in the last decade (Chan, Yin \& Chan 2010:6293). In recent years it has received increasing attention from both the academic world and industries (Jayant, Gupta \& Garg 2012:87; Nikolaou \& Evangelinos 2013:53). This is because of competition and marketing motives, direct economic motives and environmental concerns, as well as strategic and managerial implications (Dowlatshahi 2005:3456; Ravi \& Shankar 2005:1012). With legislative measures tightening up (Ravi \& Shankar 2005:1012) and a growing concern for the environment to use materials effectively and efficiently (Wang, Zhou \& Ren 2010:336), organisations do not have any choice but to engage in reverse logistics practices (Ravi \& Shankar 2005:1012).

Reverse logistics, which is sometimes referred to as 'logistics backward' because of its flow of goods, is opposite to the flow of the conventional supply chain (BearingPoint 2008:27; Steven 2004:163). Reverse logistics denotes a set of planning, execution and flow-control measures for raw materials and finished products, with the aim of recovering and recycling those products or materials. It involves a whole range of activities, including collection, sorting, processing and reconditioning (BearingPoint 2008:27). Once labelled as the forgotten child of the supply chain' (Gupta \& Tiwari 2009:3), reverse logistics has not enjoyed an attractive reputation; this is because of the misconception that it is only a cost drain and it adds no value to the supply chain (Mukhopadhyay \& Setaputra 2006:716). However, if the products are returned it does not necessarily mean that they do not have any value (De Brito 2003:17).

Traditionally, organisations have focused on improving their forward logistics activities, however, most have not treated the reverse logistics process with the same care and diligence afforded to traditional areas of logistics (Jian \& Xu 2006:1089). They generally hold that the flow of goods in a supply chain typically ends with the consumer (Jian \& Xu 2006:1089; Kim 2001:1; Sople 2007:184). With a new consciousness for the environment, this situation is beginning to change. Many organisations now consider the cost and impact of reverse logistics when designing products, rather than forward considerations such as manufacturing costs, marketability and sales margins (Doherty 2009:1; Jian \& Xu 2006:1089; Monaham, Van den Bossche \& Harthan 2004:22).

Many factors influence the implementation of effective reverse logistics and many barriers exist that complicate putting efficient and effective reverse logistics processes into place (Ravi \& Shankar 2005:1027). Reverse logistics is an issue that organisations need to master; it is important to develop a reverse logistics system that rivals traditional outbound channels in terms of efficiency, cost-effectiveness and competitiveness (Smith 2005:180). Managing the reverse supply chain is an entirely different process; where credit returns, warranty replacements, exchanges, repairs and end of leases occur (Kim 2001:1). 
One of the biggest pressures that organisations have to face with regard to reverse logistics is reducing costs (Pollock 2010:8). Despite the fact that managing returns incurs substantial cost through logistics, inventory and disposal, many organisations appear to employ inadequate processes for dealing with these returns. Given the tightness of margins in many organisations, it is worth emphasising that the improved management of these returns can have a significant impact on the bottom-line performance (Cullen, Bernon \& Grost 2010:2).

Though different from forward logistics or other areas of supply chain management, the way to explore reverse logistics in a structured manner has not yet been completely identified and described. As reverse logistics has become an item of concern to professionals only relatively recently, it has not been studied widely in the literature (Rogers, Melamed \& Lembke 2012:107). Even though organisations experience various problems and challenges in reverse logistics, the focus of this study was on cost-related problems that organisations experience with regard to reverse logistics. The purpose of this study was to analyse literature on reverse logistics, particularly to identify solutions or practices from literature, as well as to develop a conceptual framework of practices that may address the cost-related problems in reverse logistics. In addition, a survey was conducted based on the findings from literature in order to refine the framework and to determine if these practices are perceived as being important and implementable in South African organisations. This study thus provides a framework with which to prioritise practices that may be considered, adapted or adopted by organisations to reduce reverse logistics costs.

\section{Overview of reverse logistics}

Reverse logistics is essentially the opposite of logistics. The Council of Supply Chain Management Professionals defined logistics as the: process of planning, implementing, and controlling procedures for the efficient and effective transportation and storage of goods including service, and related information from the point of origin to the point of consumption for the purpose of conforming to customer requirements (CSCMP 2010:151).

Reverse logistics, on the other hand can be defined as a:

specialised segment of logistics focusing on the movement and management of products and resources after the sale and after delivery to the customer.

It 'includes product returns for repair and/or credit'. Reverse logistics is a process that enables organisations to become more environmentally capable through recycling, reusing, and reducing the amount of materials used (CSCMP 2010:151).

Although, reverse logistics processes may comprise the same activities as forward logistics, such as transportation, inventory and storage (Huscroft et al. 2013:230), the reverse logistics flow is very different from the forward flow (TibbenLembke \& Rogers 2002:271). The reverse logistics flow is more reactive and with less visibility than normal logistics. Organisations normally do not initiate reverse logistics activity as a result of planning and decision-making, but in response to actions by consumers or downstream channel members (Rogers et al. 2012:107).

A basic reverse logistics process consists of collection, inspection, sorting and disassembly as well as disposal. Before disposal is considered, the organisation can decide on any element of reverse logistics. For instance, if the organisation decides that the product can be reused, repaired or refurbished it can go directly back to the distribution process. If remanufacturing is decided upon, the product will move back to the manufacturer. On the other hand, if recycling is decided upon, the products will move back through to the original supply chain. Figure 1 provides a graphical presentation of the definition and concept of reverse logistics.

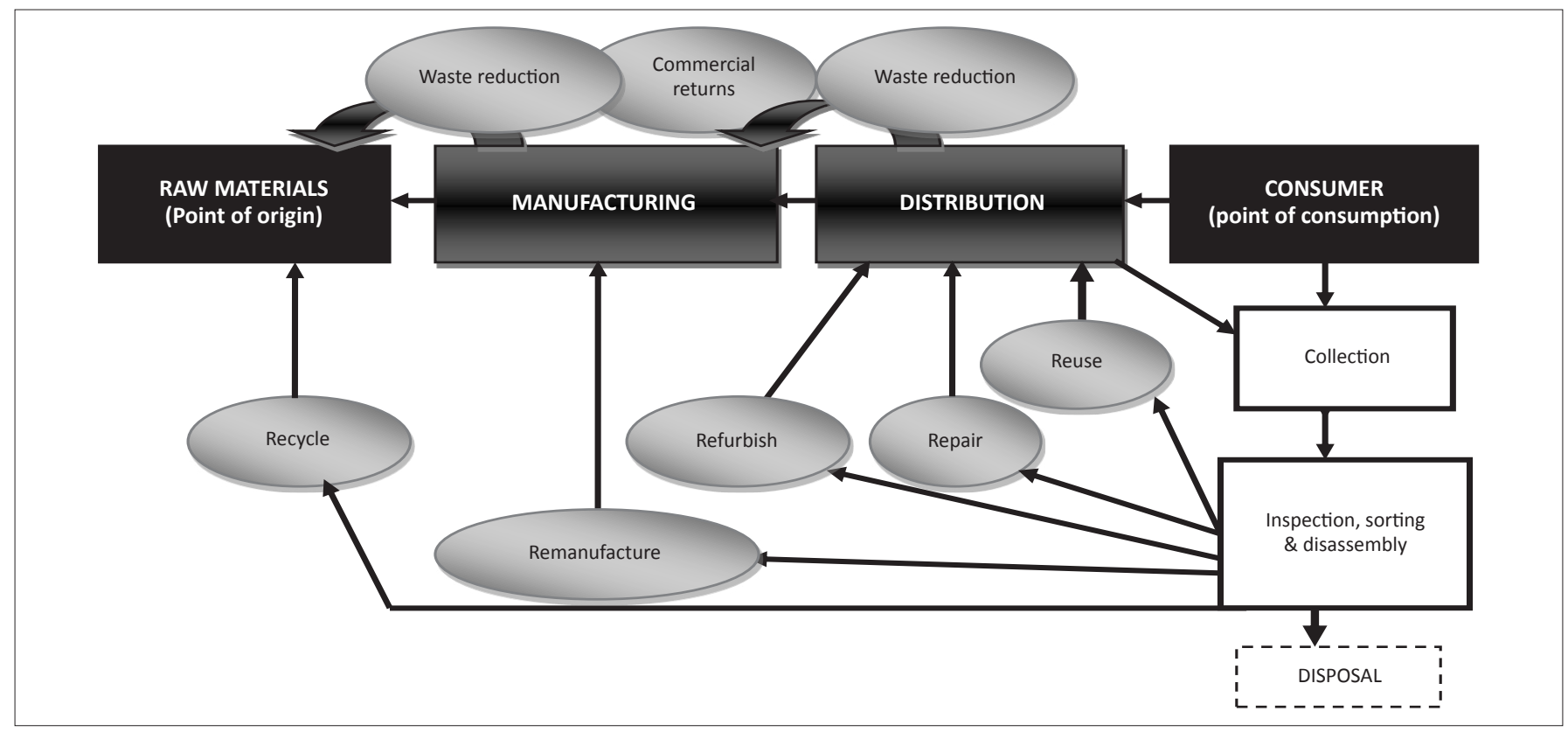

FIGURE 1: The reverse logistics process. 
In Figure 1, it is clear that materials flow backwards to the original source of the original supply chain. However, reverse logistics does not necessarily start with the end user; it can also happen during the distribution process through productionwaste by-products or commercial returns. Reverse logistics activities can cover retailers, manufacturers and service entities, and can also cut across organisational functions such as: marketing; operations; logistics; distribution and transportation; finance and accounting; customer service; quality; purchasing; design and engineering (Dowlatshahi 2005:3456, 2011:1).

It is clear that reverse logistics consists of numerous activities and elements and can be viewed in a holistic or narrow sense. It is important for organisations to manage the entire process efficiently and effectively in order for them to understand all aspects of reverse logistics.

\section{Cost problems in reverse logistics}

Rivalry between organisations in the global market puts more pressure on organisations to reduce costs (Abdullah, Yaakub \& Abdullah 2012:845). In the current economic climate, it is hard enough to manage the forward flow of products to customers, let alone having to think about the reverse flow (Mollenkopf 2010:1). Despite the growing importance of reverse logistics, most executives choose to focus their attention on the forward supply chain only, because its impact on an organisation's bottom line is far more substantial than that of reverse logistics. However, by doing so, logistics managers are missing opportunities to improve their organisations' profits and performances (Agrawal 2012:1).

Reverse logistics requires high investment and a high proportion of the logistics cost (Jayant et al. 2012:88). In the retail and manufacturing sectors, it is estimated that reverse logistics accounts for about $5 \%-6 \%$ of the total logistics cost (Jayant et al. 2012:88). Processing a returned item is much more complex and involves many more transactions than the forward supply chain (Rupnow 2012:39). The increase in costs for processing returns is an astounding $200 \%-300 \%$, in comparison with a forward sale. It can therefore be said that it costs up to three times more to process the reverse logistics of a new item than to process the forward logistics to sell it (Norman \& Sumner 2007:2). Furthermore, reverse logistics activities are limited by the infrastructure of the forward logistics activities, which can be a limiting factor in optimising reverse logistics. This results in extra costs that further dampen the motivation of organisations to handle reverse logistics (Chan et al. 2010:6294). Organisations scarcely view returns as part of their centralised cost structure (Biederman 2006:2) and by not addressing this component of the supply chain run the risk of escalating costs (Pogorelec 2000:1).

Determining the costs associated with reverse logistics can be quite complicated due to the enormous amount of details involved (Lee, McShane \& Kozlowski 2002:151). Most organisations are not aware of the current costs associated with reverse logistics. Reasons could be that processes are poorly defined and the systems lack the necessary support (Moore 2006:10; UPS Consulting 2004:3). UPS Consulting adds that there are hidden costs in reverse logistics, which can be severely underestimated. The challenge for organisations is to determine how much the existing processes are costing them, especially when they have not disbursed the resources in order to determine what the true costs are (Schwartz 2000:100). Most organisations do not understand the operational cost of returns because these costs often become buried in the financial line items of facility operations (Mollenkopf 2010:1). Hidden costs remain a factor in reducing profits (Lambert, Riopel \& AbdulKader 2011:565). Examples of hidden costs may include (Walden 2005:1):

- merchandise credits to the customer, where the defects are not covered by the supplier under warranty

- costs of processing the returns back to the distribution centre

- transportation costs of moving the items back to the central returns centre

- costs of testing and repackaging materials

- storage costs in the warehouse

- disposal costs if the items are damaged beyond repair.

It is clear from the above-mentioned reverse logistics activities that labour costs will form an important part of the reverse logistics process. In addition, certain costs cannot be easily quantified, as would be the case for loss of reputation or environmental impact. These costs, despite the inherent difficulty in estimating their true value, cannot be ignored when designing a reverse logistics system (Lambert et al. 2011:565). Whilst effective reverse logistics activities generally result in value reclamation and increased cash inflows, there can be periods where significant unexpected cash outflows can occur. This is a result of the time it takes between the moment the organisation recovers the value from the returned product and the assumption of costs incurred in the reverse logistics process (Horvath, Autry \& Wilcox 2005:193). It is clear that identifying reverse logistics costs is of great importance (Lambert et al. 2011:565; Mollenkopf 2010:1) and that the main issues include high costs that are often hidden and not always easy to quantify. Due to the page limitations and aim of the study, the individual cost items and reverse logistics practices will not be discussed in detail.

\section{Possible practices to overcome cost- related problems in reverse logistics}

In the last two decades, researchers have made an effort to determine how reverse logistics costs can be reduced and to establish an effective and efficient reverse logistics infrastructure (Chan et al. 2010:6294). There are opportunities available to reduce costs, recover value and improve customer service (Rupnow 2012:39).

From literature, a number of practices were identified that can assist organisations in overcoming cost-related problems in reverse logistics. These practices include: information 
technology; data collection and information sharing; efficient reverse logistics processes; gatekeeping; centralisation; policies, guidelines and programmes; and third-party logistics (3PL).

\section{Information technology}

Information technology application is the most important link in a reverse logistics system (Zheng, Zheng \& Liu 2005:853). Increasingly, organisations are finding it necessary to develop capabilities related to the use of information technology (Daugherty et al. 2005:83). By investing in wireless technology for the reverse logistics process, such as radio frequency identification technology (RFID), an organisation can handle its reverse flow more cost-effectively. Wireless technologies reduce manpower and human error, which in turn cut costs and improve the bottom line (Caston 2008:34). In essence, by investing and applying the right state-of-the art technology in logistics, organisations can reduce operating costs of reverse logistics (Pollock 2008:25).

\section{Information sharing and data collection}

Reducing, or even preventing, returns is one of the best solutions that organisations can use to overcome the various problems in reverse logistics. Return prevention involves the collection of information that will enable the organisation to eliminate or minimise future returns (Harps 2002:3). Organisations can reduce returns by using returns data to uncover and remove the causes of product defects; to investigate loading and packaging practices that cause damage; and to improving shipping accuracy (Harps 2002:3). Therefore, through effective data collection and interpretation, organisations can reduce returns incidences, which will improve customer service and reduce costs (O’Neill \& Chu 2001:8; Rupnow 2006:30, 2010:50).

Another solution involves information sharing. It is important for organisations to share information with their partners in the supply chain. By sharing and integrating information with supply chain partners, organisations can minimise costs, realise faster turnaround times and speed in the return processes, as well as improve customer service (Olorunniwo \& Li 2010:460; Rupnow 2007:1).

\section{Return merchandise authorisation system}

Organisations can also make use of a return merchandise authorisation (RMA) system, which is a system used to make the RMA process more efficient and effective. It is essentially the authorisation given to a customer to return a product to a seller (or supplier) (Rogers \& Tibben-Lembke 1998:262). Returns merchandise authorisation can also involve a reference number produced to recognise a faulty product and give authority for it to be returned to a distribution centre or manufacturer (CSCMP 2010:160). The RMA system can be utilised to overcome the uncertainty in the timing of product returns as well as high costs (Kuzeljevich 2004:38; Mollenkopf \& Closs 2005:42; Patrican \& Kirk 2009:14). Such a system allows organisations to gain valuable information about each item being returned. It allows customers to choose which items are being returned and the reason for the return, before the return shipment takes place. An RMA system will therefore also improve customer service (Dampier 2006:22; Mollenkopf \& Closs 2005:42). By using a web-based RMA system linked to an Enterprise Resource Planning (ERP) system, it can cut costs by up to $80 \%$. Organisations that implement these systems often achieve return on investment in a remarkably short time (Reece \& Norman 2006:1).

\section{Reverse logistics processes}

In terms of reverse logistics processes, there are a number of approaches to limit costs. For instance, organisations can streamline, automate and standardise their reverse logistics processes and set structured processes.

Streamlining reverse-logistics processes is vital in order to increase the bottom-line profitability and to reduce costs (Patrican \& Kirk 2009:15; Riedel 2004:1). By actively managing the reverse flow of products and setting structured processes, organisations can realise substantial cost savings (Verstrepen \& Neyens 2007:38). Organisations could also automate their entire reverse logistics process (Kim 2001:2; Norman \& Sumner 2007:2; Patrican \& Kirk 2009:14; Pollock 2010:9). Automation can cut costs significantly (Rowlands 2002:2) and also help organisations to get an insight into the supply chain, which will further enable them to cut shipping and labour costs (Hammrich 2007:28). Therefore, by automating the reverse logistics process, organisations can realise significant cost savings (Norman \& Sumner 2007:2; Patrican \& Kirk 2009:14; Pollock 2010:9). On the other hand, setting structured processes or standardising the reverse logistics process can help organisations manage the reverse logistics process more efficiently and effectively, as well as reduce costs and create visibility into overall returns (Genchev, Richey \& Gabler 2011:257; Patrican \& Kirk 2009:14; Pollock \& Dutta 2009:27; Pollock 2010:9). In essence, the reverse logistics process should be uncomplicated, convenient and quick; if organisations can process returns faster, they can achieve significant cost savings (Greer 2004:1; Murphy 2007:4; O'Neill \& Chu 2001:8; Rogers 2010:38; Rupnow 2010:50; Smith 2005:170).

\section{Gatekeeping}

Gatekeeping is another possible solution to overcoming cost-related problems in reverse logistics. Organisations should consider establishing a gatekeeper, which is usually the customer service department, at the start of the reverse logistics process (Hoffman 2006:1). The gatekeeper identifies returns, verifies receipts, inspects the product and makes informed decisions about accepting the return or directing it elsewhere (Hoffman 2006:1), which can reduce system costs (Rogers \& Tibben-Lembke 1998:88). A robust gatekeeping function will make the entire reverse flow more manageable and profitable (Murphy 2007:4; Patrican \& Kirk 2009:14; Ravi \& Shankar 2005:1015; Rogers \& Tibben-Lembke 1998:38). In essence, by having a gatekeeper at the start of the reverse 
logistics process with a robust gatekeeping function, the entire reverse logistics process can become more efficient and effective, which will lead to cost reductions (Harrington 2006:15).

\section{Centralisation of reverse logistics}

Centralisation refers to the number of locations at which similar activities are carried out (Fleischmann et al. 2000:660). In order to have more streamlined processes in place and give reverse logistics a greater degree of focus, organisations should separate reverse logistics facilities from forward logistics facilities (Gooley 2002:42; Patrican \& Kirk 2009:15).

Although merchandise gets shipped in both forward and reverse logistics, the conditions are very different. Forward centres are designed to ship goods out and they handle goods that are already organised in pallets and boxes in uniform sizes. Return centres, on the other hand, receive a wide range of products that are returned in any type of box or package (Dutton 2010:1). By centralising the return processes, organisations can realise cost savings, improve the quality of returns processing, overcome visibility and quality problems as well as improve information management (Rogers \& Tibben-Lembke 1998:50).

\section{Policies, guidelines and programmes}

Organisations need to have a formal approach to reverse logistics that will enable them to reduce the costs of doing business (Murray 2007:16). By establishing policies, guidelines and programmes for reverse logistics, organisations can overcome numerous problems and challenges. It is therefore necessary for organisations to establish clear, uniform and formalised policies and rules for reverse logistics (Mollenkopf \& Closs 2005:43; Monaham et al. 2004:21; Murphy, 2007:6; Patrican \& Kirk 2009:13).

There are certain policies that organisations can consider in order to minimise reverse logistics costs. For instance, organisations can implement return avoidance policies or zero-return policies to reduce returns and costs (Agrawal 2012:1; Rogers \& Tibben-Lembke 1998:61). However, these are harsh policies in terms of customer service. Alternatively, organisations can implement customer-focused policies. With these policies, organisations can increase sales, thus enabling them to reap the benefits of enhanced customer service (O'Neill \& Chu 2001:17). Therefore, organisations can either implement policies that reduce or eliminate product returns, or they can implement liberal policies where they accept returns in order to improve customer service, and in doing so, balance the costs in the reverse logistics process (Biederman 2004:1).

Apart from policies and guidelines, organisations also need to develop innovative, sophisticated and formalised reverselogistics programmes (Autry 2005:755; Dutton 2010:2, Greer 2004:1; Richey, Genchev \& Daugherty 2005:237). They will improve the end-customer's experience, realise cost savings, improve the management of inventory and return flow, and obtain a competitive advantage in the market place (Autry 2005:755; Dutton 2010:2, Greer 2004:1; Richey et al. 2005:237). Efficient and well-managed reverse logistics programmes can bring forth significant cost savings in inventory carrying, transportation and waste-disposal cost, as well as improve organisations' competitive positions (Dampier 2006:22).

\section{Third-party logistics}

Organisations are increasingly becoming aware of the importance of reverse logistics and are progressively outsourcing their reverse logistics operations (Meng 2008:518). If organisations find the costs of reverse logistics too much of a challenge, they can make use of third-party logistics (3PL) providers. According to Hugo, Badenhorst-Weiss and Van Biljon (2004:318), 3PL providers are organisations that specialise in a range of logistics services with the aim of selling these services to organisations that are typically involved in manufacturing and distribution activities'. Third-party logistics providers have the ability to cut costs at every point of the reverse logistics process (Cain 2008:15) and can help save the organisation money and time (Smith 2005:179). Therefore, 3PL providers offer cost savings and other advantages over performing reverse logistics activities in-house (Rogers et al. 2012:111).

Based on the literature review, some practices have been identified that can assist organisation to reduce costs of reverse logistics. These practices were used as the basis for this study in order to determine the most important and implementable practices.

\section{Research strategy}

One of the aims of this study was to determine the practices in reverse logistics that can assist organisations to overcome the problems and specific cost-related problems in reverse logistics.

In this study, a survey was conducted using a questionnaire, which was compiled from the reverse logistics problems and practices identified in the literature. The questionnaire consisted of two parts: (1) Part one contained the general information for the study; (2) Part two included questions. Part two comprised of three sections, namely: general information of the participating organisations, problems and challenges in reverse logistics and practices in reverse logistics. In the questionnaire for this study a Likert-type response format was used for some of the items. The respondents were asked to rate the importance and applicability of certain practices used in overcoming cost-related problems by means of a five-point Likert-type response format, with items ranging from 1 (lesser extent) to 5 (greater extent). In Part three of the questionnaire, an additional response format was included in order to determine the degree of difficulty in implementing the practices. The responses stretched from (1) very easy, to (2) somewhat easy, (3) moderately difficult, (4) somewhat difficult and (5) extremely difficult. 
Nonprobability sampling and purposive sampling methods were used for this study. Judgemental sampling is a type of purposive sampling, where the researcher selects sample members to fit some criteria (Cooper \& Schindler 2003:201). It therefore enables researchers to select cases that will best enable them to achieve their research objectives (Saunders, Lewis \& Thornhill 2012:287). In this study it was necessary to select respondents who met certain criteria. Respondents (managers at organisations) who offer reverse logistics as a service or specialise in reverse logistics in South Africa were selected in the sample.

The research population for this research included South African organisations that specialise in reverse logistics or provide logistics as a service to organisations that outsource their reverse logistics functions. In an initial search, using Google, it was found that only a few logistics organisations actually specialise in reverse logistics or provide it as a service in South Africa. Since only these companies could be included in the study, judgemental sampling was used. The sample included 19 organisations that either specialise in reverse logistics or provide it as service.

In order to increase the sample size, the questionnaire was subsequently forwarded to the members of the Chartered Institute of Logistics and Transport South Africa (CILTSA). Most of their members do not engage in reverse logistics practices. However, two organisations indicated that they do practice reverse logistics and were willing to participate. Two responses were thus received, which were then included in the sample. The nonprobability sample thus included 21 organisations.

Initial contact was made via email, explaining the purpose of the study and requesting assistance in completing the questionnaire. Thirteen organisations responded and ten completed the questionnaire. The positions or titles of the participants who completed the questionnaire ranged from managing directors to a commercial manager, a logistics manager and a general manager.
The limitations of this study are the small sample and the fact that only ten respondents took part and could be included in the analysis. This study made use of descriptive statistics to analyse the data. By using radar graphs (gap analysis) and portfolio matrixes (opportunity analysis) the data were used to conduct a gap and opportunity analysis. The results were used to compile a framework, with which to prioritise practices, that South African organisations can consider, adapt and/or adopt to reduce costs in reverse logistics.

\section{Discussion of results}

In Part three of the questionnaire, respondents were asked to indicate the importance of the practices, as well as any difficulty in implementing them. The mean values of the results were used to conduct a gap and opportunity analysis. Table 1 provides the mean values. This was done in order to determine whether the identified practices were in fact relevant and important, also whether they were difficult to implement. In terms of the importance of each practice, a mean value above three indicates that the practice is important from at least a moderate to a greater extent. In terms of the difficulty to implement each practice, a mean value above three indicates that the practice may be too costintensive or difficult to implement; therefore, organisations should carefully consider the cost-benefit trade-off levels before considering implementing it.

\section{Gap analysis}

The radar graph below (Figure 2) shows the mean level of: (1) the extent of the contribution of each of the practices, and (2) the difficulty of implementing each of these practices.

From the graph, the following most significant observations can be made about the practices:

- The practice of establishing effective data collection has a high contribution mean level (4.00) and the difficulty implementing it is fairly low - with a mean value of 2.33 . This practice is thus important and not too difficult to implement.

TABLE 1: Mean values of the importance and difficulty in implementing practices.

\begin{tabular}{|c|c|c|c|}
\hline Number & Practice & Mean values: Importance & Mean values: Difficulty in implementing \\
\hline 1 & Investing and applying the correct state-of-the-art technology & 3.90 & 2.90 \\
\hline 2 & Establishing effective data collection for return prevention & 4.00 & 2.33 \\
\hline 3 & Sharing and integrating information with supply chain partners & 4.20 & 2.70 \\
\hline 4 & Utilising an Returns merchandise authorisation system & 3.50 & 2.80 \\
\hline 5 & Streamlining the reverse logistics process & 4.10 & 3.10 \\
\hline 6 & Setting structured processes & 4.20 & 2.50 \\
\hline 7 & Automating the reverse logistics process & 3.80 & 4.00 \\
\hline 8 & Standardising the reverse logistics process & 4.30 & 2.10 \\
\hline 9 & Establishing an uncomplicated reverse logistics process & 4.30 & 2.30 \\
\hline 10 & Establishing a reverse logistics process that is quick & 4.10 & 2.60 \\
\hline 11 & Implementing a robust gatekeeping function & 3.90 & 2.67 \\
\hline 12 & Centralising return processes & 3.60 & 3.70 \\
\hline 13 & Implementing return avoidance policies or zero-return policies & 3.50 & 3.15 \\
\hline 14 & Implementing customer-focused policies & 4.00 & 2.78 \\
\hline 15 & Developing an innovative reverse logistics programme & 4.33 & 3.22 \\
\hline 16 & Developing a formalised reverse logistics programme & 4.20 & 3.33 \\
\hline 17 & Outsourcing reverse logistics to third-party logistics providers & 3.56 & 3.22 \\
\hline
\end{tabular}


- The practice of setting structured processes for reverse logistics has a high mean in terms of its contribution (4.20) and the effort implementing it is moderately low (2.50).

- The practice of standardising the reverse logistics process has a high mean level (4.30) in terms of its contribution and a low mean level (2.10) in terms of the difficulty implementing it. This practice is thus extremely important and not too cost-intensive to implement.

- Similar to the above, the practice of establishing an uncomplicated reverse logistics procedure has a high mean level (4.30) in terms of its contribution and a relatively low mean level (2.30) for implementing it. Thus, this is also a vital practice and not too difficult to implement.

- The practice of implementing customer-focused policies has a high contribution mean level (4.00) and the difficulty implementing it is fairly low - with a mean value of 2.78 . This practice is thus important and not too difficult to implement.

Hence, these five practices will contribute to a great extent in overcoming cost-related problems in reverse logistics and they are not too difficult to implement. According to the gap analysis (in Figure 2), organisations should therefore start implementing these practices first in order to realise cost savings in reverse logistics:

- The practice of automating the entire reverse logistics process has a relatively high mean level of 3.80 in terms of its contribution, but the difficulty of implementing this practice has a higher mean level of 4.00 . Hence, it would be deemed an important practice, but implementing it could be very difficult and a decision about this practice should be carefully considered in terms of value delivered to the organisation.

\section{Opportunity analysis}

An opportunity analysis was subsequently conducted to determine the extent of the contribution of the practices in relation to the difficulty implementing them. These practices are discussed by means of a portfolio matrix (see Figure 3). The portfolio matrix has the following four quadrants:

- White elephant - signifies those practices with a low level of contribution (low mean values - less than 3) that are difficult to implement (high mean values - higher than 3)

- Bread and butter - signifies those practices with a low level of contribution, but which are easy to implement (low mean values - less than 3 )

- Oyster - signifies those practices that are important, but are difficult to implement (high mean values - higher than 3)

- Pearl - signifies those practices that are important (high mean values - higher than 3) and are relatively easy to implement (low mean values - less than 3).

Figure 3 illustrates the portfolio matrix for the practices to overcome cost-related problems.

The portfolio matrix indicates that all the practices used to overcome cost-related problems in reverse logistics, that were identified in the literature study, are indeed perceived

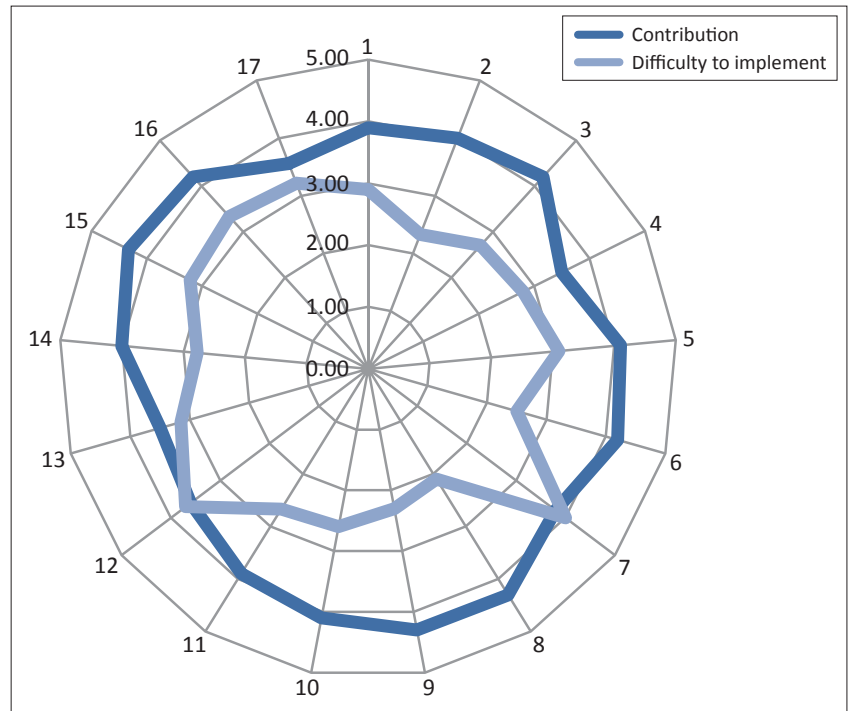

FIGURE 2: Contribution and/or difficulty implementing practices to overcome customer-related problems.

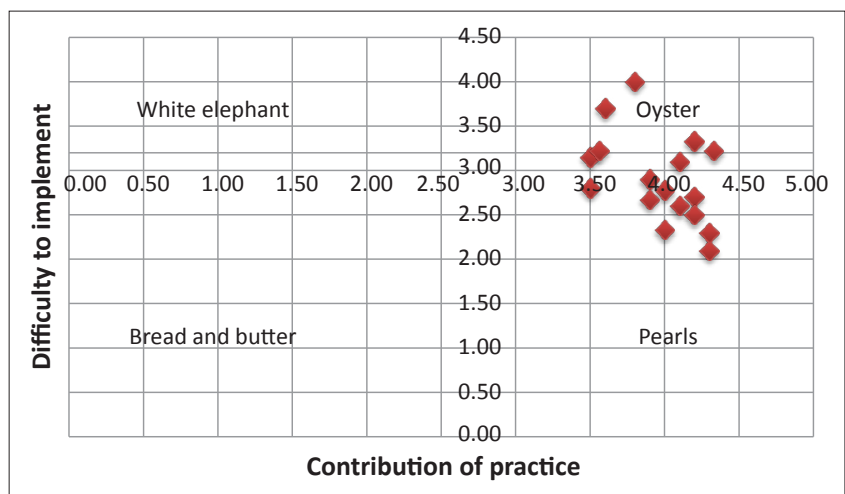

FIGURE 3: Contribution versus difficulty in implementing practices to overcome cost-related problems.

to contribute, at least to a moderate extent, to the efficient management of reverse logistics (mean values above 3 ). Furthermore, practices in the Pearl quadrant (10 of the 17 listed) are considered to be those that can potentially add value and which are not too difficult to implement. These practices should be an organisation's first priority. The remaining seven practices are all in the Oyster quadrant, indicating that they may require a lot of effort, or may be potentially cost-intensive to implement and the benefitcost trade-off should be carefully considered before these practices are implemented.

\section{A framework for prioritising practices used to overcome cost problems in reverse logistics}

Table 2 contains those practices that are important and not too difficult to implement (Pearl quadrant); therefore, organisations should consider implementing these practices first.

Table 3 contains those practices that are important, but may be too difficult to implement (Oyster quadrant); organisations should therefore carefully look at the cost-benefit trade-off before implementing these practices. 
TABLE 2: Reverse logistics practices in the Pearl quadrant: First priority.

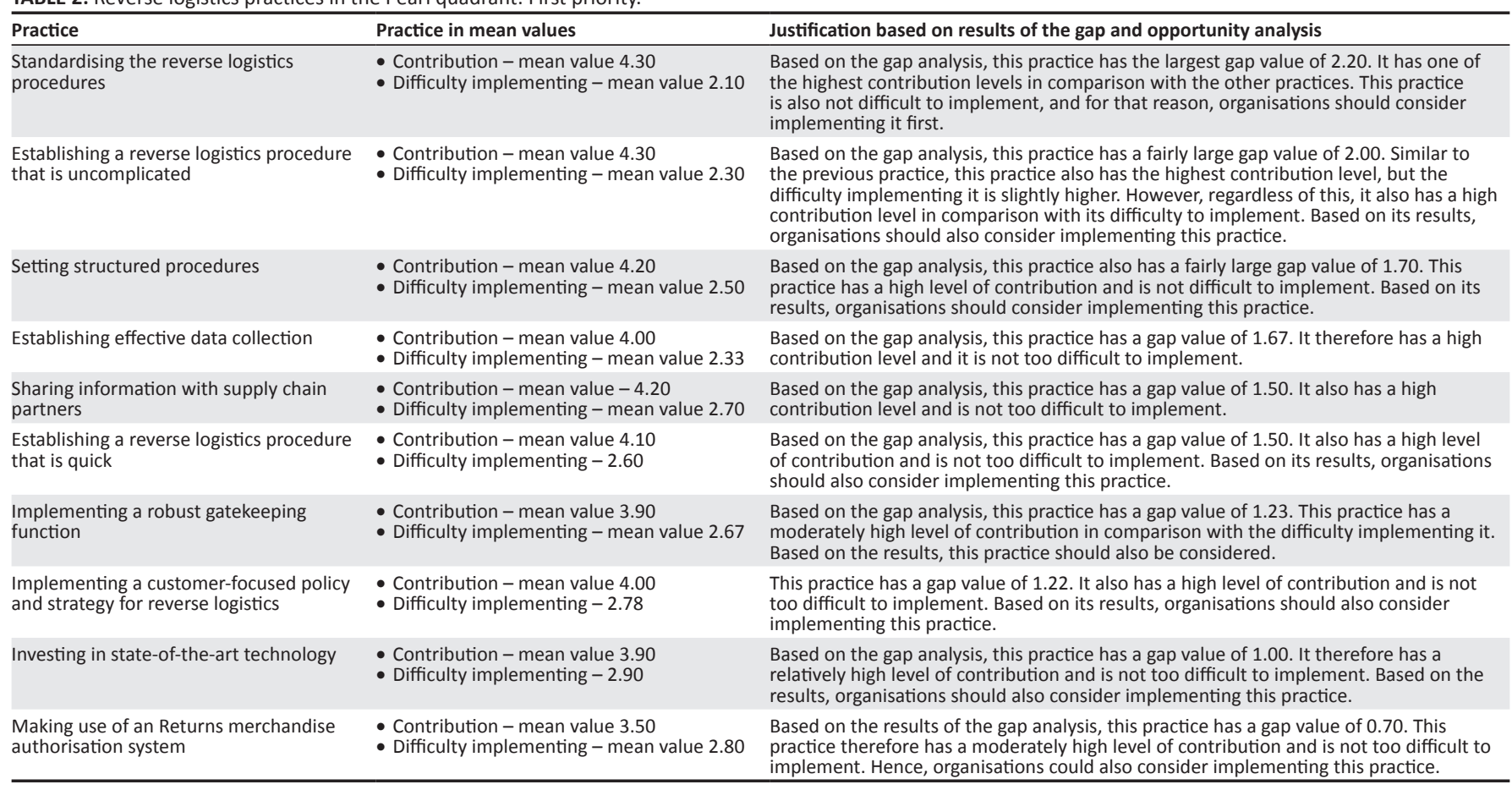

TABLE 3: Reverse logistics practices in the Oyster quadrant: Second priority.

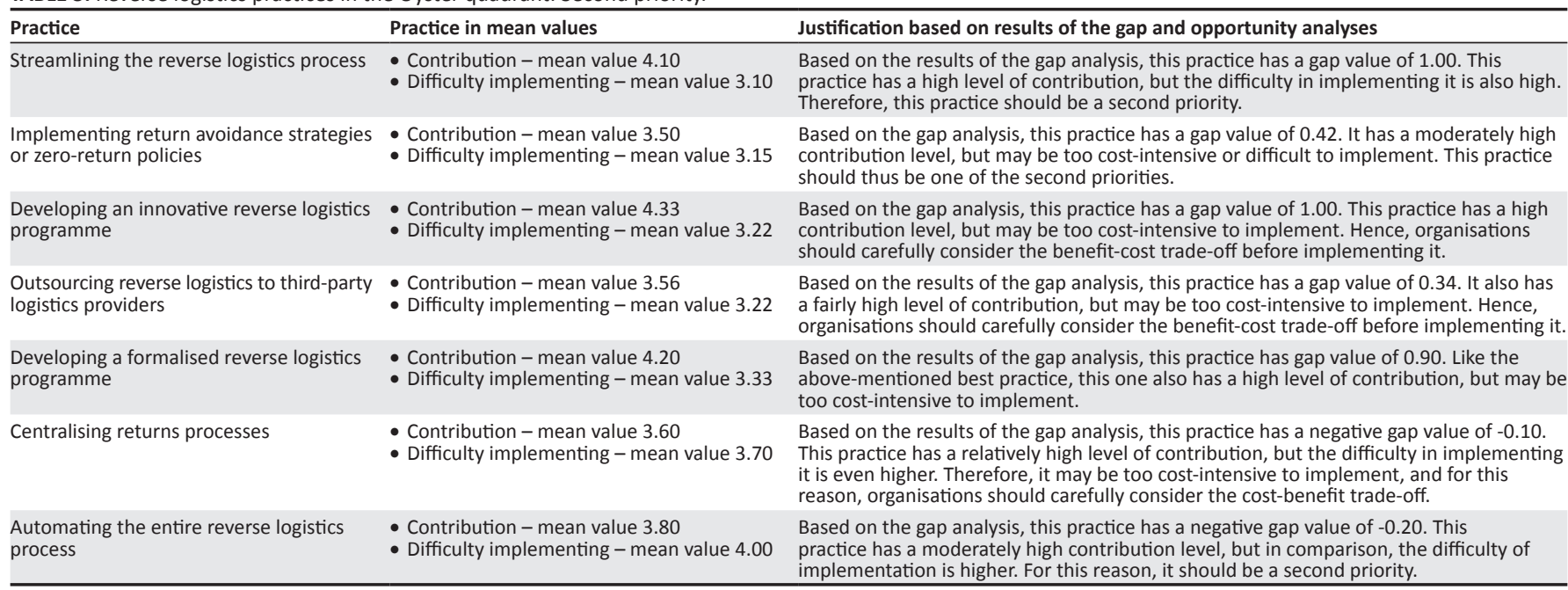

From the above results, it is clear that all the practices identified in the literature study are indeed perceived as being important; however, some are more difficult to implement than others. Therefore, according to the above framework, organisations should carefully consider the costbenefit (or resource-benefit) trade-off of each practice before considering implementing it.

\section{Conclusion}

Reverse logistics is a process that plans, implements and controls the flow of goods and information from the point of consumption to the point of recovery for the purpose of waste-reduction, recapturing value and proper disposal. Reverse logistics is important and of great significance, and if managed correctly, can provide organisations with numerous opportunities. However, organisations are not always aware that, if managed correctly, they can reduce costs, enhance revenue and improve customer satisfaction.

Although there are many challenges that organisations can experience with regard to reverse logistics, the focus of this study was on cost-related problems. The most significant cost-related problems in reverse logistics include the high costs associated with reverse logistics, high investment requirements for the successful management of reverse logistics, as well as the hidden costs of reverse logistics. On the other hand, there are numerous ways or practices to overcome the cost-related problems in reverse logistics, which involve: information technology; data collection and information sharing; RMA systems; reverse logistics processes; gatekeeping; centralisation; policies, guidelines and programmes and 3PL. 
Organisations experience numerous cost-related problems in reverse logistics and many of these organisations do not know how to deal with such problems. The purpose of this study was to identify possible practices to overcome costrelated challenges in reverse logistics. With a literature study, practices were identified. A survey conducted amongst organisations that practice reverse logistics determined the importance of the practices to overcome cost-related problems in reverse logistics. Furthermore, the survey also determined how difficult the different practices would be to implement. A framework to prioritise practices emerged from the inputs of the literature and the survey.

The framework can be used by organisations as a tool to identify the practices, which they can consider implementing in order to overcome their cost-related problems in reverse logistics. This research can also serve as a starting point for further research studies, where other problem areas in reverse logistics could be addressed.

It is no surprise that almost every organisation is looking for ways to increase sales, decrease costs and reduce risks (Greve \& Davis 2012:4). In essence, the way in which returns are managed can have a significant impact on revenues and profits (Agrawal 2012:2). If ignored, critical reverse logistics functions can cost organisations millions in lost profits due to damaged customer relationships and external liabilities that could have a considerable effect on their business. On the other hand, effectively managed reverse logistics could enable organisations to find hidden profits, improve customer satisfaction and minimise liabilities (Greve \& Davis 2012:4).

\section{Acknowledgements}

Marthi Pohl(University of South Africa) assisted in designing the questionnaire and data preparation for statistical analysis.

\section{Competing interests}

The author declares that she has no financial or personal relationship(s) that may have inappropriately influenced her in writing this article.

\section{References}

Abdullah, N.A.H.N., Yaakub, S. \& Abdullah, H.H., 2012, 'The impact of customer and stakeholder pressure, financial and competitive pressure, regulatory pressure and corporate citizenship pressure on reverse logistics adoption', 2nd International Conference on Management proceedings, pp. 842-852, viewed 08 September 2012 from http://www.internationalconference.com.my/proceeding/2nd_icm 2012 proceeding/063_125_2ndICM2012_Proceeding_PG0842_0852.pdf

Agrawal, A., 2012, 'Turn your reverse supply chain into a profit center', CSCMP's Supply Chain [Quarterly], Quarter 1, viewed 07 September 2012, from http://www. supplychainquarterly.com/topics/Strategy/201201reverse/ Autry, C.W., 2005, 'Formalisation of reverse logistics programs: A strategy for managing
liberalized returns', Industrial Marketing Management 34, 749-757, viewed 16 June 2010, from www.sciencedirect.com

BearingPoint, 2008, 'How mature is the green supply chain? 2008 Supply Chain Monitor' Insight - Survey Report, viewed 08 July 2011, from http://supplychainstandard admin.madgex.com/assets/getAsset.aspx?liAssetID $=530$

Biederman, D., 2004, 'Turning logistics around', Traffic World, viewed 15 October 2009, from $h$ ttp://proquest.umi.com

Biederman, D., 2006, 'Planning for happy returns', Traffic World, viewed 15 October 2009, from http://proquest.umi.com
Cain, R., 2008, 'Turning returns into revenue: Why leaving your reverse logistics to the experts puts more cash into your pockets', Reverse Logistics Magazine, 11th edn., 3(3), 12-15, viewed 26 August 2009, from http://www.rlmagazine.com/ edition11p12.php

Caston, J., 2008, 'Integrating reverse logistics with wireless technology', Reverse Logistics Magazine, 10th edn., 3(2), 34-36, viewed 25 April 2011, from http://www.rlmagazine. com/edition10p34.php

Chan, H.K., Yin, S. \& Chan, F.T.S., 2010, 'Implementing just-in-time philosophy to reverse logistics systems: A review', International Journal of Production Research 48(21) 6293-6313, viewed 08 September 2012, from http://0-www.tandfonline.com. oasis.unisa.ac.za/doi/full/10.1080/00207540903225213

Cooper, D.R. \& Schindler, P.S., 2003, Business research methods, 8th edn., McGraw-Hill, New York.

CSCMP (Council of Supply Chain Management Professionals), 2010, Supply chain and logistics terms and glossary, viewed 25 June 2010, from http://cscmp.org/digital/ glossary/glossary.asp

Cullen, J., Bernon, M. \& Grost, J., 2010 'Tools to manage reverse logistics', Research executive summaries series 6(3), 1-8, viewed 08 July 2012, from http://www. cimaglobal.com/Documents/Thought_leadership_docs/cid_ressum_tools_manage reverse_logistics_apr2010.pdf

Dampier, J., 2006, 'Leverage reverse logistics to increase customer loyalty and operational efficiency', Reverse Logistics Magazine, 1st edn., 1(1), 22, viewed 08 January 2009, from http://www.rlmagazine.com/edition01p22.php

Daugherty, P.J., Richey, R.G., Genchev, S.E. \& Chen, H., 2005, 'Reverse logistics: Superior performance through focused resource commitments to information technology', Transportation Research Part E: Logistics and Transportation Review 41, 77-92, viewed 27 August 2011, from http://www.sciencedirect.com/science/ article/pii/S1366554504000195

De Brito, M.P., 2003, 'Managing reverse logistics or reversing logistics management?', (ERIM PhD Series Research in Management), University Rotterdam, Erasmus, viewed 15 January 2009, from http://repub.eur.nl/res/pub/1132/

Doherty, K., 2009, 'Sustainability: Reverse logistics forward thinking in returns management', Food Logistics, viewed 09 October 2011, from http://www.food logistics.com/article/10255802/sustainability-reverse-logistics

Dowlatshahi, S., 2005, 'A strategic framework for the design and implementation of remanufacturing operations in reverse logistics', International Journal of Production Research 43(16), 3455-3480. http://dx.doi.org/10.1080/00207540500118118

Dowlatshahi, S., 2011, 'A framework for the role of warehousing in reverse logistics' International Journal of Production Research, 1-13, viewed 08 February 2012 from http://www.tandfonline.com/doi/abs/10.1080/00207543.2011.571922

Dutton, G., 2010, 'Reverse logistics: Money tree or money pit?', World Trade - WT100, viewed 03 September 2011, from http://www.worldtradewt100.com/articles/ reverse-logistics-money-tree-or-money-pit

Fleischmann, M., Krikke, H.R., Dekker, R. \& Flapper, S.D.P., 2000, 'A characterization of logistics networks for product recovery', The International Journal of Management Science 28(6), 653-666.

Genchev, S.E., Richey, R.G. \& Gabler, C.B., 2011, 'Evaluating reverse logistics programs: Suggested process formalisation', International Journal of Logistics Management 22(2), 242-263, viewed 10 January 2012, fromwww.emeraldinsight.com/09574093.htm

Gooley, T.B., 2002, 'The who, what and where of reverse logistics', Logistics Management 42 (2), 38-44, viewed 15 October 2009, from http://proquest.umi.com

Greer, R., 2004, 'Leveraging a successful reverse logistics program to increase customer loyalty and operational efficiency', Reverse Logistics Trends Newsletter (5), 1-2, viewed 15 October 2009, from http://www.reverselogisticstrends.com/newsletters/ 2004_09_nl.htm

Greve, C. \& Davis, J., 2012, 'Recovering lost profits by improving reverse logistics', White paper 1-17, viewed 08 September 2012, from http://grevedavis.com/ files/2012/03/Reverse_Logistics_White_Paper1.pdf

Gupta, A. \& Tiwari, G., 2009, 'Reverse logistics management: An effective strategy for revenue maximization in CPG Industry', Wipro Technologies, viewed 15 January 2010, from http://www.wipro.com/documents/insights/whitepaper/Reverse Logistics_for_Revenue_Maximization.pdf

Hammrich, D., 2007, 'Taking a look back helps retailers stay a step ahead: Tapping into hidden revenues with returns management', Reverse Logistics Magazine 5 th edn., 2(2), 28-29, viewed 07 July 2010, from http://www.rlmagazine.com/ edition05p28.php

Harps, L.H., 2002, 'Getting started in reverse', Inbound Logistics, viewed 20 November 2009, from http://www.inboundlogistics.com/cms/article/getting-started-inreverse-logistics/

Harrington, R., 2006, 'Reverse logistics: Customer satisfaction, environment key to success in the 21st century', Reverse Logistics Magazine, 1st edn., 1(1), 14-15, viewed 17 April 2009, from http://www.rlmagazine.com/edition01p14.php

Hoffman, W., 2006, 'Shifting into reverse: As supply chains grow more complex, shippers realize need for a separate returns process for speed, cost savings', Traffic World, Commonwealth Business media, viewed 15 October 2009, from http://proquest. umi.com

Horvath, P.A., Autry, C.W. \& Wilcox, W.E., 2005, 'Liquidity implications of reverse logistics for retailers: A Markov chain approach' Journal of Retailing 81(3), 191-203. http://dx.doi.org/10.1016/j.jretai.2005.07.003

Hugo, W.M.J., Badenhorst-Weiss, J.A. \& Van Biljon, E.H.B., 2004, Supply chain management: Logistics perspective, Van Schaik, Pretoria.

Huscroft, J.R., Hazen, B.T., Hall, D.J. \& Hanna, J.B., 2013, 'Task-technology fit for reverse logistics performance', International Journal of Logistics Management com/journals.htm?articleid $=17094583 \&$ show $=$ abstract 
Jayant, A., Gupta, P. \& Garg, S.K., 2012, 'Perspectives in reverse supply chain management (R-SCM): A state of the art literature review', Jordan Journal of Mechanical and Industrial Engineering 6(1), 87-102.

Jian, L. \& Xu, S., 2006, 'Research on problems faced in the process of developing reverse logistics', International Conference of Management Science and Engineering proceedings, 1089-1094, viewed 01 November 2011, from www.seiofbluemountain. com/search/detail.php?id=578

Kim, H., 2001, 'Manufacturers profit by managing reverse supply chains', Logistics Management, viewed 10 October 2009, from http://www.logisticsmgmt.com/ article/CA73190.html

Kuzeljevich, J., 2004, 'Targeting reverse logistics', Canadian Transportation Logistics 107(9), 36-39, viewed 27 July 2011, from www.ctl.ca

Lambert, S., Riopel, D. \& Abdul-Kader, W., 2011, 'A reverse logistics decisions conceptual framework', Computer and Industrial Engineering 61(3), 561-581. http://dx.doi. org/10.1016/j.cie.2011.04.012

Lee, J., McShane, H. \& Kozlowski, W., 2002, 'Critical issues in establishing a viable supply chain/reverse logistics management program', 2002 IEEE International Symposium - Electronics and the Environment, viewed 30 June 2010, from http://ieeexplore. ieee.org

Meng, X., 2008, 'Study of evaluation and selection on third party reverse logistics providers', International Seminar on Business and Information Management, pp.
$518-528$, viewed 09 October 2009, from http://ieeexplore.ieee.org/xpls/abs_all. $518-528$, viewed 09 Octo
jsp?arnumber $=5117541$

Mollenkopf, D.A. \& Closs, D.J., 2005, 'The hidden value in reverse logistics', Supply Chain Management Review 9(5), 34-43, viewed 15 January 2010, from http://proquest. umi.com/login

Mollenkopf, D.A., 2010, 'Reverse logistics - effective returns management in an integrated supply chain', Supplychain Management Review, viewed 02 August 2012, from http://www.scmr.com/article/effective returns_management in an integrated supply_chain

Monaham, S., Van den Bossche, P. \& Harthan, C., 2004, 'Shifting your supply chain into reverse', Executive Agenda 7(3), 18-27, viewed 22 October 2009, from www. atkearney.com/shared_res/pdf/EA73_ShiftingSupplyChain_S.pdf

Moore, J, 2006, 'Reverse logistics: The least used differentiator', Reverse Logistics Magazine, 4th edn., 1(4), 10-11, viewed 19 October 2009, from http://www. rImagazine.com/edition04p10.php

Mukhopadhyay, S.K. \& Setaputra, R., 2006, 'The role of 4PL as the reverse logistics intergrator: Optimal pricing and return policies', International Journal of Physical Distribution and Logistics Management 36(9), 716-729, viewed 15 Septembe 2009, from http://www.emeraldinsight.com/journals.htm?articleid=1576166

Murphy, J.V., 2007, 'Best practices in reverse logistics can ease the pain of product returns', Global Logistics and Supply Chain Strategies, viewed 27 July 2011, from http://www.supplychainbrain.com/content/logisticstransportation/serviceparts-management/single-article-page/article/best-practices-in-reverse-logisticscan-ease-the-pain-of-product-returns/

Murray, S., 2007, 'Hidden beauty of the "uglies"', Financial Times, 1st edn., p. 16, viewed 20 October 2010, from http://www.ft.com/cms/s/1/04d70020-03be-11dc-a931 000b5df10621.html\#axzz1qsGt0TK6

Nikolaou, I.E. \& Evangelinos, K.I., 2013, 'A framework for evaluating the social responsibility quality of reverse logistics', in Y. Nikolaidis (ed.), Quality management in reverse logistics, Springer, London. http://dx.doi.org/10.1007/978-1-4471-4537-0_4

Norman, L. \& Sumner, W., 2007, 'Reverse logistics: The bearer of good fortune', Take Supply Chain, News Articles, viewed 27 August 2011, from http://www. takesupplychain.com/news-article-11-30-07.php

O'Neill, S. \& Chu, J., 2001, 'Online returns management strategies', IBM Global Service eStrategy Report, viewed 17 October 2009, from http://lenovo-img.sitecelerate. $\mathrm{com} /$ services/pdf/IBM_Consulting_Online_returns management.pdf

Olorunniwo, F.O. \& Li, X., 2010, 'Information sharing and collaboration practices in reverse logistics', Supply Chain Management: An International Journal 15(6), 454462. http://dx.doi.org/10.1108/13598541011080437

Patrican, J. \& Kirk, K., 2009, 'Competing and reversing revenue loss with aftermarke services', Reverse Logistics Magazine, 18th edn., 4(4), 12-15, viewed 18 Sepetember 2011, from www. RLmagazine.com

Pogorelec, J., 2000, 'Reverse logistics is doable, important', Frontline Solutions 1(10), 68-69, viewed 28 October 2009, from http://search.ebscohost.com/login.aspx?d irect=true $\& d b=b t h \& A N=3575321 \&$ site=ehost-live

Pollock, B. \& Dutta, S., 2009, 'Driving returns in the reverse logistics service chain', Reverse Logistics Magazine, 16th edn., 2(4), 26-29, viewed 20 July 2011, from www.RLmagazine.com

Pollock, W.K., 2008, '10 rules for successful reverse logistics operations', Reverse Logistics Magazine, 9th edn., 3(1), 22-26, viewed 18 June 2010, from www.RLmagazine.com
Pollock, W.K., 2010, 'Driving return process directly to the bottom line', Reverse Logistics Magazine, 21th end., 5(3), 8-12, viewed 29 June 2011, from www.RLmagazine.com

Ravi, V. \& Shankar, R., 2005, 'Analysis of interactions among the barriers of reverse logistics', Technological Forecasting \& Social Changes 72, 1011-1029, viewed 22 October 2009, from www.sciencedirect.com.

Reece, J. \& Norman, L., 2006, 'The six hidden costs of reverse logistics', Inbound Logistics, viewed 07 August 2011, from http://www.inboundlogistics.com/cms/ article/the-six-hidden-costs-of-reverse-logistics/.

Richey, R.G., Genchev, S.E. \& Daugherty, P.J., 2005, 'The role of resource commitment and innovation in reverse logistics performance', International Journal of Physical Distribution and Logistics Management 35(4), 233-257, viewed 16 September 2009, from www.emeraldinsight.com

Riedel, M., 2004, 'Turning returns to profits', Traffic World, viewed 15 October 2009, from http://proquest.umi.com

Rogers, D.S. \& Tibben-Lembke, R.S., 1998, 'Going backwards: Reverse logistics trends and practices', Reverse Logistics Executive Council, viewed 02 August 2007, from http://www.rlec.org/reverse.pdf

Rogers, D.S., Melamed, B. \& Lembke, R.S., 2012, 'Modeling and analysis of reverse logistics', Journal of Business Logistics 33(2), 107-117, viewed 08 September 2012, from http://onlinelibrary.wiley.com/doi/10.1111/j.0000-0000.2012.01043.x/pdf

Rogers, L.K., 2010, 'Reverse logistics: Learn from your returns', Modern Materials Handling, September, 36-39, viewed 23 May 2011, from http://www.mmh.com/ article/reverse_logistics_learn_from_your_returns/

Rowlands, P., 2002, 'Back to the Future? New thinking on product returns', Fulfilment and e-Logistics, viewed 20 August 2011, from http://www.elogmag.com/magazine/ 18/feature1.shtml

Rupnow, P., 2006, 'Maximizing performance at your reverse logistics operations', Reverse Logistics Magazine, 1st edn., 1(1), 28-35, viewed 17 September 2009, from www. RLmagazine.com

Rupnow, P., 2007, 'The power of exchanging data with your reverse logistics partners', Reverse Logistics Association Newsletter (37), 1-3, viewed 20 November 2009, from http://www.reverselogisticstrends.com/newsletters/2007_08_nl.htm.

Rupnow, P., 2010, 'Returning thoughts: Reverse logistics outlook and challenges for 2010', Reverse Logistics Magazine, 22nd edn., 5(4), 50, viewed 15 August 2011 from www.RLmagazine.com

Rupnow, P., 2012, '7 steps to successful reverse logistics operations', Reverse logistics magazine, 41st edn., 7(7), 39-40, viewed 28 October 2012, from www.RLmagazine. com

Saunders, M., Lewis, P. \& Thornhill, A., 2012, Research methods for business students, 6 th edn., Pearson Education, Harlow, UK.

Schwartz, B., 2000, 'Reverse logistics strengthens supply chains', Transportation and Distribution 41(5), 95-98, viewed 16 August 2009, from http://proquest.umi.com

Smith, A.D., 2005, 'Reverse logistics programs: Gauging their effects on CRM and online behaviour', Journal of Information and Knowledge Management Systems 35(3), 166-181, viewed 15 June 2011, from www.emeraldinsight.com

Sople, V.V., 2007, Logistics management: The supply chain imperative, Pearson Education, Dorling Kindersley, India.

Steven, M., 2004, 'Networks in reverse logistics', in H. Dyckhoff, R. Lackes \& J. Reese (eds.), Supply chain management and reverse logistics, Springer, Heidelberg. http:// dx.doi.org/10.1007/978-3-540-24815-6_8

Tibben-Lembke, R.S. \& Rogers, D.S., 2002, 'Differences between forward and reverse logistics in a retail environment', Supply Chain Management, An International Journal 7(5), 271-287, viewed 20 September 2011, www.emeraldinsight.com.

UPS Consulting, 2004, 'Reverse logistics: The least used differentiator', UPS Consulting, White Paper, 1-10, viewed 16 September 2009, from http://www.ups-scs.com/ solutions/whitepapers3.html

Verstrepen, S. \& Neyens, K., 2007, 'Huge reverse logistics savings potential exists in the heart of Europe', Reverse Logistics Magazine, 5th edn., 2(2), 38-39, viewed 22 October 2009, from www.RLmagazine.com

Walden, J.W., 2005, 'Reverse logistics: Important or irritant' Supply Chain Advanced Network (S.C.A.N.), viewed 12 August 2009, from http://www.honeycombconnect. com/Supply_Chain_Management/document_5567.ashx?page=Supply_Chain_ Management_home \&datasource $=427$

Wang, P., Zhou, G. \& Ren, J., 2010, 'Research on structure of reverse logistics network', International Conference of Logistics Engineering and Management 2010 (ICLEM 2010) proceedings 1(5), 336-362, Chengdu, China.

Zheng, Y., 2005, 'Research on information integration management of reverse logistics', in W. Zheng \& P. Liu (eds.), 7th International conference on Electronic commerce: ICEC 2005 Conference proceedings, 133, 851-855 ACM, NY, viewed 18 November 2011, from http://dl.acm.org/citation.cfm?doid=1089551.1089718 